\section{Misuse of dihydrocodeine tartrate (DF 118) among opiate addicts}

\author{
Harith Swadi, Brian Wells, Robert Power
}

Medway Health Authority, Chatham, Kent ME4 6DL Harith Swadi, MRCPSYCH, consultant child and adolescent psychiatrist

\section{Riverside Health}

Authority, London SW1

Brian Wells, MRCPSYCH,

consultant psychiatrist

Department of Psychiatry, Charing Cross and Westminster Medical

School, London W6

Robert Power, PHD, senior research fellow

Correspondence to: Dr Swadi.

Br. Hed f 1990;300:1313

Evidence of the misuse of dihydrocodeine preparations remains largely anecdotal, ${ }^{12}$ consisting of case reports of dependence mainly among users of the proprietary form of dihydrocodeine tartrate DF 118. Recent estimates of the extent of dihydrocodeine misuse in the general population and among drug users are lacking. This paper reports the results of an investigation into the level of DF 118 misuse (excluding other dihydrocodeine preparations) among opiate addicts at a London treatment centre.

\section{Methods and results}

The clinic notes of all opiate addicts at a central London drug dependency treatment centre were inspected for the results of their first pretreatment urine test. Gas spectrometry was used to detect various substances. With this method it was possible to detect different types of opiates as well as different types of dihydrocodeine preparations. Clients were also asked

about past and current use of DF 118. At the time of the study (July 1988) there were 143 active clients on the register for opiate addiction, 99 men and 44 women, with mean ages of 30 and 28 years respectively. This figure excluded four clients undergoing treatment for benzodiazepine dependence and one for cocaine dependence, but none gave a positive result for DF 118 on urine testing and only one benzodiazepine dependent client reported DF 118 misuse in the past. Among the 143 clients positive urine tests were recorded for the following substances: DF 118 31, amphetamine 21, barbiturates 79, benzodiazepines one, cocaine one, codeine 38 , heroin 122 , methadone 71 , morphine 101 , phenothiazines 11 ,

Age and sex distribution of opiate addicts in each category and numbers misusing DF 118

\begin{tabular}{|c|c|c|c|c|c|c|}
\hline \multirow[b]{2}{*}{ Age (years) } & \multicolumn{2}{|c|}{ Men } & \multicolumn{2}{|c|}{ Women } & \multicolumn{2}{|c|}{ Total } \\
\hline & Total & $\begin{array}{c}\text { DF } 118 \\
\text { users }\end{array}$ & Total & $\begin{array}{c}\text { DF } 118 \\
\text { users }\end{array}$ & Total & $\begin{array}{c}\text { DF } 118 \\
\text { users }\end{array}$ \\
\hline$<21$ & 8 & 1 & 4 & 1 & 12 & 2 \\
\hline $21-25$ & 22 & 7 & 10 & 3 & 32 & 10 \\
\hline $26-30$ & 31 & 6 & 17 & 5 & 48 & 11 \\
\hline $31-35$ & 11 & 5 & 7 & 2 & 18 & 7 \\
\hline$>35$ & 27 & 10 & 6 & 3 & 33 & 13 \\
\hline Total & 99 & 29 & 44 & 14 & 143 & 43 \\
\hline
\end{tabular}

\title{
Somatostatin analogue treatment for malignant hypercalcaemia
}

\section{Harrison, N James, K Broadley, S R Bloom, R Armour, S Wimalawansa, D Heath, J Waxman}

Hypercalcaemia is common in malignant disease and occurs in 5\% of patients.' Humoral hypercalcaemia is thought to relate to the ectopic production of parathyroid hormone related peptide. ${ }^{2}$ We describe the successful treatment with octreotide, a somatostatin and other dihydrocodeine preparations six. The table shows the age distribution of the clients and the prevalence of DF 118 misuse in both sexes in each age category. In addition to the 31 DF 118 users detected by urine testing 12 others reported that they occasionally or frequently used DF 118 as an opiate substitute. Therefore $43(30 \%)$ of the population had ever misused DF 118 . DF 118 misusers were equally distributed among men and women $29 \%$ and $32 \%$ respectively).

\section{Comment}

DF 118 is the proprietary name for dihydrocodeine tartrate $B P$. It is available in tablet, elixir, and injection forms and widely used as a strong analgesic. The manufacturers report that it has a "low addiction potential." This paper documents the potential for DF 118 misuse among non-prescription users. Our point prevalence estimate showed that $31(22 \%)$ of all opiate addicts undergoing treatment were using DF 118 for non-medical purposes, but this may well be an underestimate given our methods. Misuse tended to occur more commonly among established older addicts of either sex. Officially the number of opiate addicts in the United Kingdom is $5000,{ }^{4}$ but the general consensus is that there may be as many as 50000 . Thus between 1000 and 10000 opiate addicts in the United Kingdom may be consuming DF 118 on any given day.

The potential for DF 118 misuse was confirmed by clients, who reported that it is widely misused and preferred to other dihydrocodeine preparations. DF 118 is not available to NHS patients but can be obtained on private prescription. It is sold on the street for up to $£ 2$ a tablet, a highly inflated price. Ampoules of DF 118 were reported by clients to be extremely scarce.

We have little doubt that dihydrocodeine is widely misused, especially in its popular DF 118 proprietary form, and many treatment centres may wish to confirm our report. It is important that prescribers, notably general practitioners and dentists, are aware of this potential. Opiate addicts seem to prefer DF 118 to other dihydrocodeine preparations, but the reasons for this remain obscure and worth exploring. It may be reasonable to suggest that private prescribers should follow NHS policy when prescribing dihydrocodeine and use its generic form.

1 Marks P. Drug dependence caused by dihydrocodeine. Br Med f 1978;i:1594. 2 Wood P. Opiate dependence in west Yorkshire. In: Levy J, Budd K, eds. Opiond use and abuse. London: Royal Society of Medicine, 1986:37.

Asscciation of British Pharmaceutical Industry. ABPI compendium 1988-1989. London: Datapharm, 1989:427.

4 Home (Office. Home Office statistical bulletin. London: HMSO, 1988

Accepled 22 Februan 1990

analogue, of a patient with a phaeochromocytoma and diphosphonate resistant hypercalcaemia leading to decreased production of parathyroid hormone related peptide and normocalcaemia.

\section{Case report}

A 51 year old man presented in 1985 with weight loss, abdominal pain, a left sided abdominal mass, diabetes, hypertension, and hypercalcaemia. Computed tomography of the abdomen showed a retroperitoneal tumour. After excision of an adrenal phaeochromocytoma he became normotensive and normocalcaemic.

He remained well until May 1988, when he developed locally recurrent and metastatic disease with hyper- 
Departments of Oncology, and Medicine, Royal

Postgraduate Medical

School, London W12 0HS

$M$ Harrison, MRCP, registrar

$\mathrm{N}$ James, MRCP, registrar

K Broadley, MB BS, senior house officer

S R Bloom, DSC, professor

$\mathrm{S}$ Wimalawansa, MRCP,

senior lecturer

$\mathrm{J}$ Waxman, $\mathrm{MD}$, senior lecturer

Department of Surgery,

Lister Hospital, Stevenage

R Armour, FRCS, consultant

surgeon

Department of Medicine, Queen Elizabeth Hospital, Birmingham

D Heath, FRCP, reader

Department of Medicine,

Royal Postgraduate

Medical School, London W12 0NN

D Wynick, MRCP, Wellcome Trust training fellow

$\mathrm{S}$ Ball, $\mathrm{MB}$, medical senior house officer

M Barnard, MRCP, $M R C$ training fellow

S R Bloom, FRCP, professor of endocrinology

\section{Queen Elizabeth Medical Centre, Birmingham} B15 2TH

W A Ratcliffe, PHD, principal biochemist, department of clinical chemistry

D A Heath, FRCP, consultant physician, department of medicine

Correspondence to: Professor Bloom.

Br.Med f 1990;300:1314-5 calcaemia. A Meta-iodo-benzylguanidine scan showed no tumour uptake and a technetium bone scan no bone metastases. Urinary concentration of vanillylmandelic acid and serum concentrations of calcitonin, 1,25 hydroxy vitamin $\mathrm{D}$, parathyroid hormone, somatostatin, and gut peptides were normal. He was treated with cisplatin and doxorubicin chemotherapy ${ }^{3}$ given monthly for three months, but this produced no response. Chemotherapy was changed to fluorouracil, methotrexate, and lomustine. He received three treatment cycles again without response and remained consistently hypercalcaemic. By January 1989 his condition had deteriorated further, and chemotherapy was discontinued. In February 1989 his hypercalcaemia (corrected calcium of $3.36 \mathrm{mmol} / \mathrm{l}$ ) caused appreciable symptoms. The urinary concentration of vanillylmandelic acid was raised (mean $61.5 \mathrm{mmol} / 24 \mathrm{~h}$ ) without change in any other measured hormone. His hypercalcaemia was treated by hydration and with diuretics and disodium etidronate. His serum calcium remained raised. At this stage octreotide treatment was started. The dosage was increased over two days from $50 \mathrm{mg}$ to $100 \mathrm{mg}$ twice a day. There was an immediate decrease in serum corrected calcium concentration from $3 \cdot 31$ to $2 \cdot 21 \mathrm{mmol} / \mathrm{l}$, and for the first time in 18 months the patient became normocalcaemic. This was associated with a dramatic improvement in his symptoms. As a result of treatment parathyroid hormone related peptide values, which were grossly raised, fell from a pretreatment level of $3.10 \mathrm{pg} / \mathrm{l}$ to $0.9 \mathrm{pg} / 1$ measured using the PB35 antibody (intra-assay variation $<8 \%$, interassay variation $<12 \%$, assay sensitivity $0.1 \mathrm{pg} / \mathrm{l}$, no cross reactivity with parathyroid hormone fragments $1-34$ or 1-84 or with other related or unrelated peptides; levels undetectable in normal controls) ${ }^{+}$without significant change in any other hormone or in urinary vanillylmandelic acid concentrations. In situ hybridisation was performed on paraffin embedded material obtained from the original operation. Using an antisense probe parathyroid hormone related peptide mRNA was clearly shown in the tumour, while control studies with a sense probe were negative (D A Heath et al, unpublished data). The response was transient, and six weeks after starting somatostatin his serum calcium was $3.23 \mathrm{mmol} / \mathrm{l}$, but the patient remained without hypercalcaemic symptoms for a further four months.

\section{Comment}

Hypercalcaemia in malignancy may relate to humoral mechanisms or to local osteolysis. The cause for humoral hypercalcaemia has been recently described and relates to secretion of parathyroid hormone related peptide. ${ }^{2}$ Hypercalcaemia has been previously reported in phaeochromocytoma but may result from coexistent hyperparathyroidism. In our patient serum parathyroid hormone values were normal and there were no bone metastases. We showed increased serum concentrations of parathyroid hormone related peptide and its expression within the tumour itself. Our patient became normocalcaemic with treatment, and normocalcaemia was associated with a decrease in concentrations of parathyroid hormone related peptide. Somatostatin analogues may have a role in treating the humoral hypercalcaemia of malignancy, particularly in diphosphonate resistance, and this is currently under investigation.

We thank Dr G Segre of Massachusetts General Hospital for his kind gift of PB35 antibody. The antisense mRNA was donated by W Wood, Genentech Inc, San Francisco.

1 Heath DA. Hypercalcaemia in malignancy. Br Med 7 1989:298:1468-9.

2 Broadus AE. Mangin M. Ikeda K, et al. Humoral hypercalcemia of ancer. N Engl I Med 1988;319:556-63.

3 Schlumberger $M$, Ostronoff $M$, Bellaiche $M$, Rougier P, Droz JP, Parmentier C. 5-Fluorouracil, doxorubicin, and cisplatin regimen in adrenal cortical carcinoma. Cancer 1988;61:1492-4.

+ Suva J, Winslow GA, Wettenhall RE, et al. A parathyroid hormone-related protein implicated in malignant hypercalcemia: cloning and expression. Science 1987;237:893-6.

Stewart AF, Hoecker JL, Mallette LE, Segre GV, Amatruda TT, Vignery A. Hypercalcemia in pheochromocytoma. Ann Intern Med 1985;102:776-9.

Accepted 15 February 1990

\section{Treatment of a malignant pancreatic endocrine tumour secreting parathyroid hormone related protein}

\section{Wynick, W A Ratcliffe, D A Heath, S Ball, M Barnard, S R Bloom}

Hypercalcaemia associated with pancreatic endocrine tumours (islet cell tumours) is most commonly due to primary hyperparathyroidism as part of the syndrome of multiple endocrine neoplasia type I. The concentration of serum parathyroid hormone should be raised in such cases. Hypercalcaemia may also occur in association with tumours secreting vasoactive intestinal polypeptide, with low or undetectable parathyroid hormone concentrations.' If the tumour has not disseminated resecting the primary lesion cures the hypercalcaemia, thus indicating a humoral mechanism for the raised serum calcium concentration. We report on a patient with hypercalcaemia and a malignant pancreatic endocrine tumour with metastases to the liver whose tumour appeared to secrete only parathyroid hormone related protein. The long acting somatostatin analogue ocreotide was used to try to suppress the hypercalcaemia.

\section{Case report}

A 37 year old woman presented in 1985 with a one month history of right upper quadrant pain, polyuria, and lethargy. Investigations showed a corrected serum calcium concentration of $3.46 \mathrm{mmol} / \mathrm{l}$ (normal $2 \cdot 2-2 \cdot 6 \mathrm{mmol} / \mathrm{l}$ ) and a serum phosphate concentration of $0.48 \mathrm{mmol} / \mathrm{l}$ (normal $0.8-1.4 \mathrm{mmol} / \mathrm{l}$ ). The results of other haematological and biochemical tests were normal. Angiography and computed tomography showed a tumour of $5 \times 4 \mathrm{~cm}$ in the tail of the pancreas and metastases in both lobes of the liver; biopsy confirmed a malignant islet cell tumour. Over the next four years the number and size of the liver metastases slowly grew with a concurrent rise in the calcium concentration to over $3 \mathrm{mmol} / \mathrm{l}$ despite introducing oral steroids (15 mg/day), oral phosphates (1.9 $\mathrm{g}$ three times daily), and a low calcium diet $(<250 \mathrm{mg} /$ day). The biochemical findings of hypercalcaemia, hypophosphataemia with an undetectable serum parathyroid hormone (by both amino terminal and mid-molecule radioimmunoassay), and a normal ${ }^{{ }^{* m} \mathrm{~m}} \mathrm{~T} \mathrm{c}$ methylene diphosphonate bone scan suggested that the tumour was secreting parathyroid hormone related protein. A liver biopsy guided by ultrasound was performed and the specimen stained for vasoactive intestinal polypeptide, gastrin, glucagon, insulin, neurotensin, somatostatin, and pancreatic polypeptide. All were negative, which concurred with the normal plasma gut hormone estimations. ' Intense staining was present, however, for neurone specific 